\title{
Physiological maturity and relationships of growth and reproduction in the red mangrove crab Goniopsis cruentata (Latreille) (Brachyura, Grapsidae) on the coast of São Paulo, Brazil
}

\author{
Valter José Cobo ${ }^{1} \&$ Adilson Fransozo ${ }^{2}$ \\ ${ }^{1}$ Laboratório de Biologia Marinha, Instituto Básico de Biociências, Universidade de Taubaté. Avenida Tiradentes 500, 12030 - \\ 180 Taubaté, São Paulo, Brasil. \\ 2 Departamento de Zoologia, Universidade Estadual Paulista. Distrito de Rubião Júnior, 18610-000 Botucatu, São Paulo, Brasil.
}

\begin{abstract}
This investigation provided information on the physiological sexual maturity and relationships of growth and reproduction in Goniopsis cruentata (Latreille, 1803). Collections were made monthly from January 1995 through December 1996, on the northeastern coast of São Paulo State, Brazil. The crabs were grouped into juvenile males; adult males; juvenile females, and adult females, including ovigerous ones. For each specimen the carapace width (CW) was measured, and molt condition and macroscopic developmental stage of the gonad tissue were recorded. CWs of physiologically mature crabs were between 21.4 and $23.7 \mathrm{~mm}$ for both sexes. This population showed molt activity in all size groups throughout the study period, which suggests continuous growth and the absence of terminal anecdysis. This may be associated with the ability of these animals to copulate during the intermolt, supplying a high proportion of mature individuals over time and ensuring continuity of reproduction year-round.

KEYWORDS. Gonad development, molt cycle, size at maturity, Ubatuba.
\end{abstract}

RESUMO. Maturidade fisiológica e as relações entre o crescimento e a reprodução do caranguejo de manguezal Goniopsis cruentata (Latreille) (Brachyura, Grapsidae) no litoral de São Paulo, Brasil. Este trabalho fornece informações sobre as relações entre a maturidade sexual e o crescimento do caranguejo Goniopsis cruentata (Latreille, 1803). Durante o período de janeiro de 1995 a dezembro de 1996 foram realizadas coletas mensais na região de Ubatuba, litoral norte do Estado de São Paulo. Os animais capturados foram reunidos em quatro grupos de interesse: macho jovem, macho adulto, fêmea jovem e fêmea adulta, em que estão incluídas as ovígeras. Para cada animal foi mensurada a largura da carapaça (LC) e anotadas a condição de muda e o estágio do desenvolvimento gonadal. A maturidade fisiológica foi observada entre 21.4 e $23.7 \mathrm{mmLC}$ para ambos os sexos. A população amostrada apresentou atividade de muda em todas as classes de tamanho durante todo o período estudado, o que sugere o estabelecimento de um padrão de crescimento contínuo e ausência de anecdise terminal para essa espécie. Esse fato pode estar associado com a habilidade desses animais em copular durante a intermuda, gerando uma grande quantidade de indivíduos maduros durante todo o ano, garantindo a continuidade do processo reprodutivo.

PALAVRAS CHAVE. Biologia reprodutiva, desenvolvimento gonadal, Ubatuba.

Reproduction is certainly the main mechanism to guarantee continuity of a species, and is one of the most important regulatory processes for maintenance of stocks in natural populations (Сово \& Fransozo 2000). Determination of the size at which a species of brachyuran crab begins sexual activity is a key parameter to understanding its life cycle (Hartnoll \& Gould 1988). Growth and reproduction may be understood as competing for energy resources, and this competition limits the availability of these resources or the rate at which they are metabolized in either growth or reproduction (HaRTNOLL 1985). According to Adiyodi \& Adiyodi (1970), growth and reproduction are the major metabolic events that involve the recurrent mobilization of organic supply, respectively for epidermis deposition and gonad formation, and although they sometimes occur in isolation, they are inseparable and mutually integrated functions.

Research on sexual maturity has been conducted by several authors, such as Atrill et al. (1991); Freire et al. (1991), Minagawa \& Higuchi (1997), and OH \& Hartnoll (1999). In Bra- 
zil, Costa \& Negreiros-Fransozo (1998), Pinheiro \& Fransozo (1998), Reigada \& Negreiros-Fransozo (1999), Castigioni \& Santos (2001), and Silva \& Oshiro (2002) have provided some data on crab maturity. This investigation provided information on the mean size interval at which physiological sexual maturity was attained, for both males and females, as well as evaluating the interaction between growth and reproduction in a population of the red mangrove crab Goniopsis cruentata (Latreille, 1803), in an estuarine area of the northeastern coast of the state of São Paulo, Brazil.

\section{MATERIAL \& METHODS}

The red mangrove crab, G. cruentata, is a member of the brachyuran family Grapsidae. This semi-terrestrial crab is commonly found in mangrove forests, inhabiting crevices, logs and living branches of the mangrove trees, and also walking on the substratum (MeLo 1996). Monthly collections were carried out from January 1995 through December 1996, each time with a 2-hour sampling effort by three people, in an estuarine area formed by the Escuro and Comprido rivers at Ubatuba on the

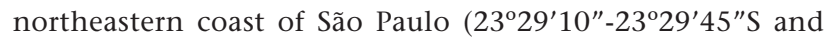
$\left.45^{\circ} 09^{\prime} 10^{\prime \prime}-45^{\circ} 09^{\prime} 00^{\prime \prime} \mathrm{W}\right)$.

In the laboratory, the crabs were sexed, based on abdomen features, and the carapace width (CW) was measured with a vernier caliper. The molt condition was estimated based on the consistency of the carapace, and was classified as either Intermolt (IM), with the carapace totally calcified; or Molt (M), with a deformable carapace or a new epicuticule present under the old exoskeleton.

The macroscopic stages of the gonad tissues were recorded and assigned to categories according to the characteristics described in table I, proposed by Сово \& Fransozo (2000). The mean size at gonad maturation, $\mathrm{L}_{50 \%}$, was estimated by fitting the data to a sigmoid curve.

\section{RESULTS}

A total of 1170 crabs were obtained, 573 males and 597 females, distributed in 11 size classes at 4-mm CW intervals, as proposed by Сово \& Fransozo (2000). Gonad maturation was recorded at $\mathrm{L}_{50 \%},=21.0 \mathrm{~mm} \mathrm{CW}$ for males and $\mathrm{L}_{50 \%},=22.6 \mathrm{~mm}$ $\mathrm{CW}$ for females. These values were included in the same size class, $20 \dashv 24 \mathrm{~mm} \mathrm{CW}$, and no significant difference was detected (Figs 1 and 2). Crabs in both molt and intermolt conditions were recorded in every month during both years of the study. The frequency of intermolt individuals was significantly higher over practically the entire period, except in September 1995 ( $\mathrm{p}>0.05$ ) (Fig. 3).

Both molt and intermolt individuals were recorded in all size classes, except that no molt crabs were recorded in the last two classes, $48 \dashv 52$ and $52 \dashv 56 \mathrm{~mm} \mathrm{CW}$. (Fig. 4) (Note that these two groups included only 5 animals.) The frequency of molt crabs was inversely proportional to gonad development, when the decrease in molt activity occurred simultaneously with the increase in frequency of the "in development" and "developed" gonadal stages (Figs 5 and 6).

\section{DISCUSSION}

The beginning of sexual maturity is a biological event of great importance, marked by several morphological, physiological, and behavioral transformations, indicating the transition from juvenile to the adult (HarTnOLl 1985).

The results of this study indicated that $G$. cruentata attains physiological maturity over the same size interval of morphological maturity proposed by Сово \& Fransozo (1998), estimated at between 20 and $24 \mathrm{~mm} \mathrm{CW}$ for males and 18 and $29 \mathrm{~mm}$ CW for females.

Among brachyuran crabs, simultaneous triggering of morphological and physiological sexual maturity has been observed in several species, e.g., by Нiatт (1948), for Pachygrapsus crassipes Randall, 1839; HaRTNOLL (1965), for Aratus pisonii (H. Milne Edwards, 1837); WATSON (1970) for Chionoecetes opilio (Fabricius, 1788) and El-Hamid (1988), for Portunus pelagicus (Linnaeus, 1758).

In G. cruentata, males and females attained sexual maturity at comparable sizes, or over a similar, small size interval. This synchrony has also been reported for other species of Grapsidae, e.g. Pachygrapsus transversus (Gibbes, 1850), (AвеLE et al. 1986), and Nanosesarma gordoni (Shen, 1935) (FukUI 1988).

Table I. Description of gonad development stages for males and females (modified from HAEFNER 1976, CHOY 1988).

\begin{tabular}{|c|c|c|}
\hline \multirow{2}{*}{ Gonad stages } & \multicolumn{2}{|c|}{ Characteristics } \\
\hline & Males & Females \\
\hline Immature (IM) & No detectable gonad under stereomicroscope & No detectable gonad under stereomicroscope \\
\hline Undeveloped (UD) & $\begin{array}{l}\text { Filamentous deferent vas, detectable under } \\
\text { stereomicroscope }(2,5 x) \text { (Translucent) }\end{array}$ & $\begin{array}{l}\text { Filamentous ovary, detectable under stereomicroscope } \\
(2,5 x) \text { (Translucent) }\end{array}$ \\
\hline Developing (DNG) & $\begin{array}{l}\text { Deferent vas beginnings thread, occupying reduced } \\
\text { volume on the body cavity. (White) }\end{array}$ & $\begin{array}{l}\text { Ovary with characteristic "H" shape, about } 1 / 4 \\
\text { hepatopâncreas volume. (Dark orange) }\end{array}$ \\
\hline Developed (DE) & $\begin{array}{l}\text { tests }+ \text { deferent vas occupying about } 1 / 4 \\
\text { hepatopancreas volume, complete threaded (White) }\end{array}$ & $\begin{array}{l}\text { Ovary occupying about } 1 / 2 \text { hepatopancreas volume. } \\
\text { (Dark brown) }\end{array}$ \\
\hline
\end{tabular}

Revista Brasileira de Zoologia 22 (1): 219-223, março 2005 

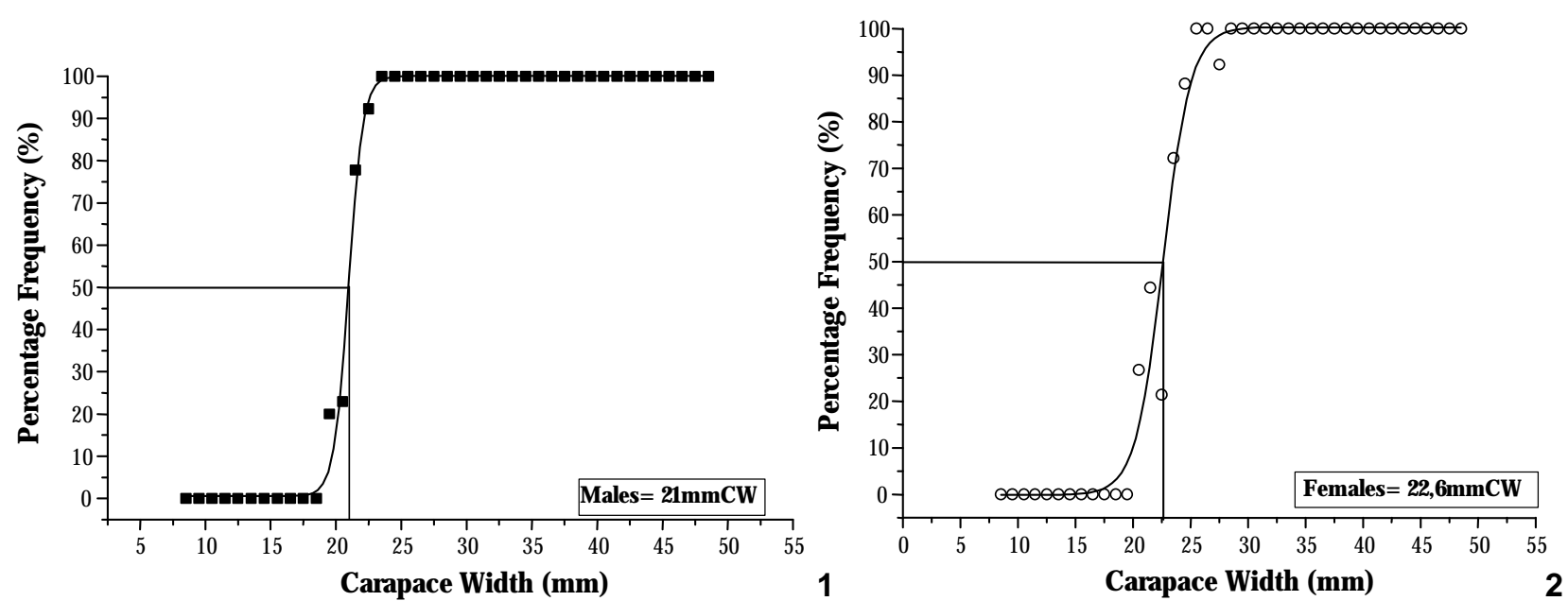

Figures 1-2. Mean size of $1^{\star}$ gonad maturation to (1) males and (2) females.
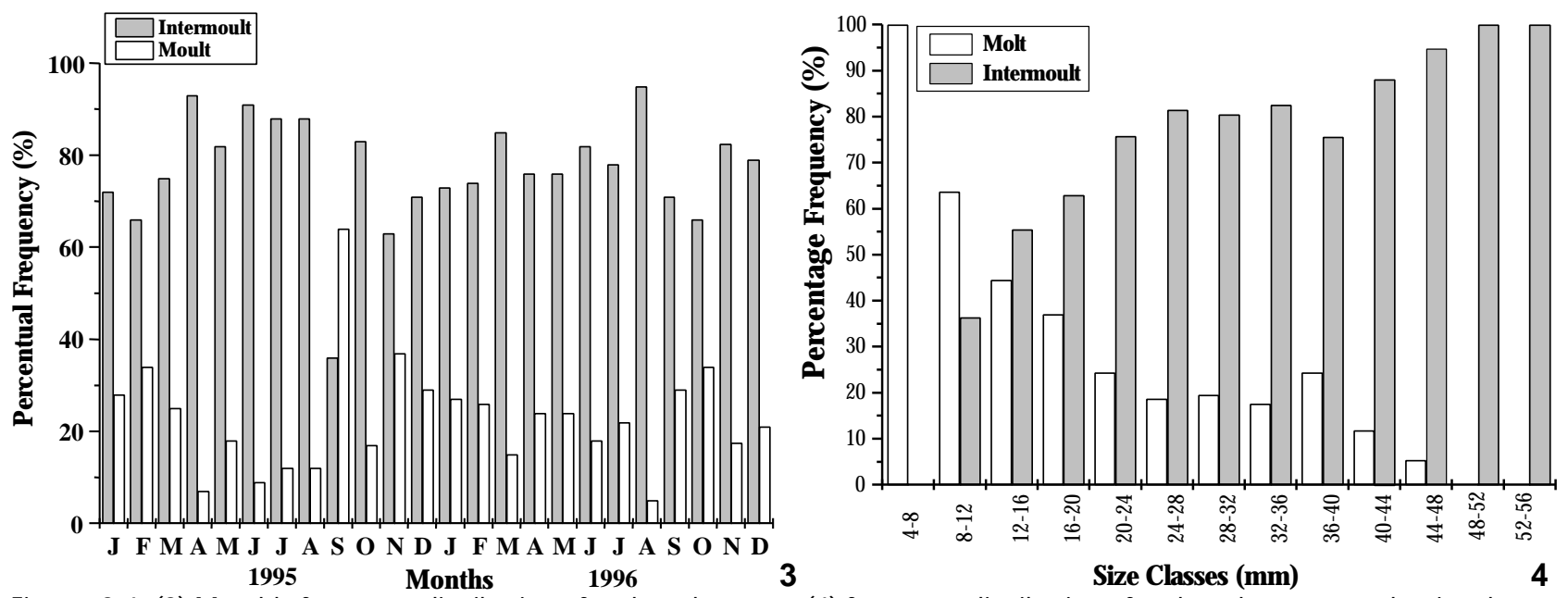

Figures 3-4. (3) Monthly frequency distribution of molt cycle stages; (4) frequency distribution of molt cycle stages on the size classes.
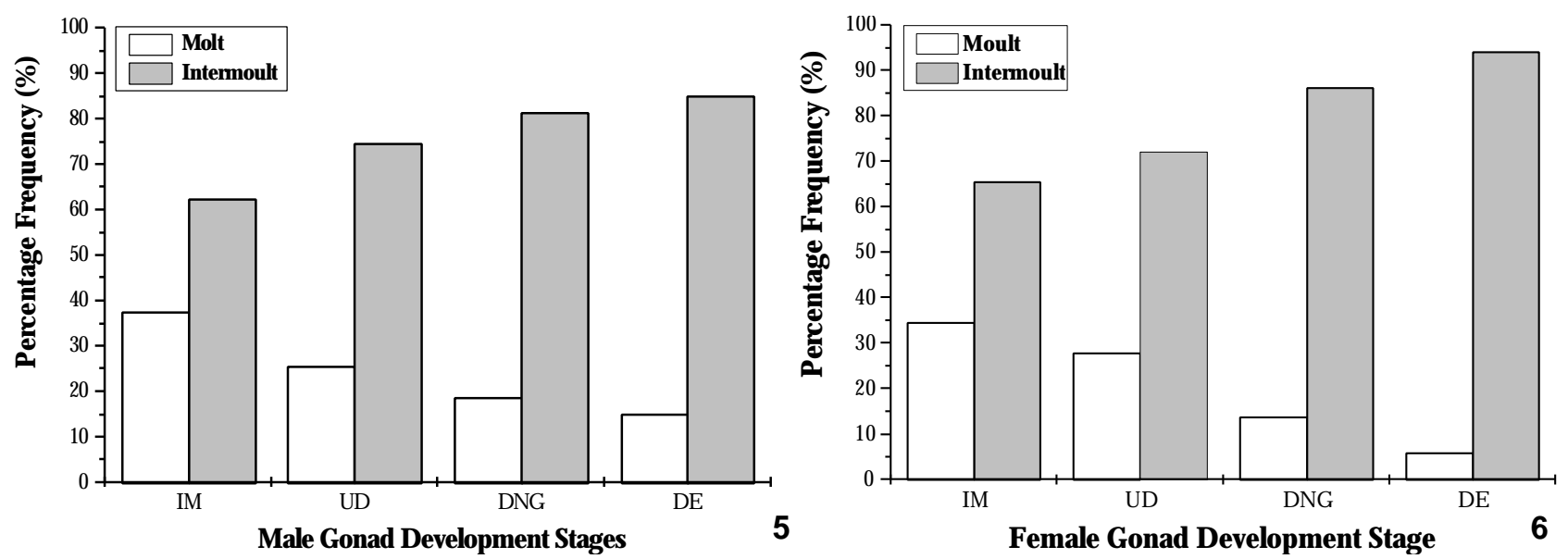

Figures 5-6. Frequency distribution of the molt cycles stages regard to the (5) male and (6) female gonad development stages.

Revista Brasileira de Zoologia 22 (1): 219-223, março 2005 
This strategy may help provide large numbers of adult crabs, able to copulate, thus maximizing reproductive effort. According to HarTnOlL \& Gould (1988), this pattern of reproductive cycle is involved in the natural process of maintaining the size of the population.

However, the growth rates for G. cruentata remain unknown. The females may perhaps grow faster than males, or vice-versa, attaining maturity at comparable sizes but at different times. This question will only be answered by studies on the growth rate of the species.

The molt activity recorded over the size classes and throughout the study period suggests that this species has a continuous growth pattern. These results concord with observations by HARTNOLL (1969), who reported the absence of permanent or terminal anecdysis in this species, unlike other animals such as Chionoecetes baiirdi Rathbun, 1924, (DonALDson 1981) and Callinectes sapidus Rathbun, 1896, (SKINNER 1985).

The high frequency of individuals in intermolt condition, over the entire sampling period, suggests that in G. cruentata there are long intervals between molts, as well as a short postmolt phase (ADIYODI \& ADIYodi 1970). This schedule is a common feature in the life cycles of crabs, especially terrestrial and semi-terrestrial crabs, that live without the supportive advantages of the aquatic environment, and certainly contributes to shorten the length of time of the post-molt phases in these crabs.

The absence of intermolt individuals in the first size class (4 $\dashv 8 \mathrm{~mm}$ LC) suggests that immature individuals must undergo subsequent ecdysis at very short time intervals. According to HarTnoll \& Gould (1988), the high molt activity observed in immature individuals represents an evident partitioning of energy resources between growth and reproduction, in which juveniles direct most of their resources toward somatic growth, whereas adult crabs must divide their energy between growth and reproduction.

On the other hand, the absence of individuals in molt condition in the last two size classes seems to reflect the maximum size reached by this species. This supposition is supported by the small number (five) of animals in these classes, suggesting a high mortality rate at these sizes.

These results imply that G. cruentata may spawn more than once in the same breeding season, especially because of its ability to copulate with a hard exoskeleton and its long intermolt period; i.e., it is an iteroparous species.

However, studies are needed to clarify during how many seasons of its adult life it is able to produce egg masses, and how many egg masses can be produced in each season, which will contribute toward broader understanding of the reproductive output of this crab.

\section{ACKNOWLEDGEMENTS}

To Dra. Maria Lúcia Negreiros-Fransozo for valuable suggestions in the manuscripts. The authors are thankful to the colleagues of NEBECC for the aid in the field collections and laboratory analyses. We also express our gratefulness to the Conselho Nacional de Desenvolvimento Científico e Tecnológico - CNPq (Proc. \#840.211/95-3) and for the Universidade de Taubaté - UNITAU (Proc. \#26-97/269-97) for the research fellowship to the first author.

\section{REFERENCES}

Abele, L.G.; P.J. Campanella \& M. Salmon. 1986. Natural history and social organization of the semiterrestrial grapsid crab Pachygrapsus transversus (Gibbes). Journal of Experimental Marine Biology and Ecology, Amsterdam, 104: 153-170.

Adiyodi, K.G. \& R.G. Adiyodi. 1970. Endocrine control of reproduction Decapod Crustacea. Biological Review, Cambridge, 45: 121-165.

Attrill, M.J.; R.G. Hartnoll \& A.L. Rice. 1991. Aspects of the Biology of the deep-sea crab Geryon trispinosus from the Porcupine Seabight. Journal of Marine Biological Association of United Kingdow, London, 71: 311-328.

Castiglioni, D.S. \& S. SAntos. 2001. Reproductive aspects of Cyrtograpsus angulatus Dana, 1851 (Brachyura, Grapsidae) in the Lagoa do Peixe, Rio Grande do Sul State, Brazil. Nauplius, Botucatu, 9 (1): 11-20.

CHоу, S.C. 1988. Reproductive biology of Liocarcinus puber and L. holsatus (Decapoda, Brachyura, Portunidae) from the Gower Peninsula, South Wales. Marine Ecology, Berlin, 9 (3): 227-241.

Сobo, V.J. \& A. Fransozo. 1998. Relative growth of Goniopsis cruentata (Crustacea, Brachyura, Grapsidae), on the Ubatuba region, São Paulo, Brazil. Iheringia, Série Zoologia, Porto Alegre, 84: 21-28.

Cobo V.J. \& A. Fransozo. 2000. Fecundity and reproduction period of the red mangrove crab Goniopsis cruentata (Brachyura, Grapsidae), São Paulo state, Brazil, p. 527-533 In: J.C. Vaupel von Klein \& F.R. Schram (Eds). The Biodiversity crisis and Crustacea. Roterdam, Crustacean Issues, 12, 848p.

Costa, T.M. \& M.L. Negreiros-Fransozo. 1998. The reproductive cycle of Callinectes danae Smith, 1869 (Decapoda, Portunidae) in the Ubatuba region, Brazil. Crustaceana, Leiden, 71 (6): 615-627.

Donaldson, W.F. 1981. Growth, age and size at maturity of tanner crab Chionoecetes bairdi M.J. Rathbun in the northern gulf of Alaska (Decapoda, Brachyura). Crustaceana, Leiden, 40 (3): 286-302.

EL-HAMID, N.F.A. 1988. Size composition sex ratio, size at maturity, mating and egg-laying in the crab Portunus pelagicus (Linnaeus). Folia Morphologica, Turin, 2 (36): 200-211.

Freire, J.; R. Muño; L. Fernández \& E. González-Gurriarãn. 1991. Life cycle of Liocarcinus arcuatus (Brachyura, Portunidae) in the Ria de Arousa (Galicia, NW Spain): Role of beach and mussel raft. Culture areas. Marine Ecology, Berlin, 12 (3): 193-210.

FukuI, Y. 1988. Comparative studies on the life history of the grapsid crabs (Crustacea, Brachyura) inhabiting intertidal

Revista Brasileira de Zoologia 22 (1): 219-223, março 2005 
cobble and bouder shores. Publications of the Seto Marine Biological Laboratory, Shirahama, 33 (4/6): 121-162.

HAEFNER, JR., P.A. 1976. Distribution, reprodution and moulting of rock crab Cancer irroratus Say, 1917, in the Mid-Atlantic Bight. Journal of Natural History, London, 10: 377-397.

HaRTNOLL, R.G. 1965. Notes on the marine grapsid crabs of Jamaica. Proceedings of the Linnean Society of London, London, 176 (2): 113-147.

Hartnoll, R.G. 1969. Mating in the Brachyura. Crustaceana, Leiden, 16: 162-181.

HARTNOLL, R.G. 1985. Growth, sexual maturity and reproductive output, p. 101-128. In: A.M. WenNer (Ed.). Factors in adult growth. Rotterdam, A.A. Balkema, 362p.

HARTNOLL, R.G. \& P. GoulD. 1988. Brachyuran life history strategies and the optimization of egg production. Symposium of the Zoological Society of London, London, 59: 1-9.

Hiatt, R.W. 1948. The biology of the line shore crab, Pachygrapsus crassipes Randall. Pacific Science, Washington, 2 (3): 134-213.

Melo, G.A.S. 1996. Manual de identificação dos Brachyura (caranguejos e siris) do litoral brasileiro. São Paulo, Ed. Plêaide, 603p.

Minagawa, M. \& S. Higuchi. 1997. Analysis of size gonadal maturaty in the spiny lobster Panulirus japonicus (Decapoda:
Palinuridae). Journal of Crustacean Biology, Lawrence, 17: 70-80.

Он, C-W. \& R.G HarTnolL. 1999. Size at sexual maturity, reproductive output, and seasonal reproduction of Philocheras trispinosus (Decapoda) in Port Erin Bay, Isle of Man. Journal of Crustacean Biology, Lawrence, 19 (2): 252-259.

Pinheiro, M.A.A. \& A. Fransozo. 1998. Sexual maturity of the speckled swimming crab Arenaeus cribrarius (Lamark, 1818) (Decapoda, Brachyura, Portunidae), in Ubatuba littoral, São Paulo State, Brazil. Crustaceana, Leiden, 71 (4): 434-452.

Reigada, A.L.D. \& M.L. Negreiros-Fransozo. 1999. Maturidade sexual em Hepatus pudibundus (Decapoda, Brachyura, Calappidae). Iheringia, Série Zoologia, Porto Alegre, 86: 159-164.

SiLva, Z.S. \& L.M.Y. Oshiro. 2002. Aspectos reprodutivos de Goniopsis cruentata (Latreille) (Crustacea, Brachyura, Grapsidae) na Baía de Sepetiba, Rio de Janeiro, Brasil. Revista Brasileira de Zoologia, Curitiba, 19 (3): 907-914.

SKInNer, D.M. 1985. Interacting factors in the control of the Crustacean molt cycle. American Zoologist, Washington, 25: 275-284.

Watson, J. 1970. Maturity, Mating, and Egg Laying in the Spider Crab, Chionoecetes opilio. Journal of Fisheries Research Board of Canada, Ottawa, 27 (9): 1606-1616.

Received in 23.XI.2004; accepted in 18.II.2005. 